\title{
Susceptibility of Some Grapevine Cultivars and Rootstocks to Crown Gall Disease
}

\author{
H. Mahmoodzadeh*and H. Doulati Baneh
}

West Azerbaijan Research Centre of Agriculture and Natural Resources, Orumia, Iran

Submitted for publication: May 2008

Accepted for publication: September 2008

Key words: Agrobacterium; Vitis vinifera L.; grafting; susceptibility; $\mathrm{NAZ}_{4}$; $\mathrm{NAZ}_{6}$

\begin{abstract}
The effects of five interspecific hybrid rootstocks on the susceptibility of grafted scions to crown gall were studied for six years in field as well as greenhouse experiments. The incidence of crown gall on susceptible grape scion cultivars (Vitis vinifera cvs. 'Thompson seedless' and 'Red Sahebi') was not affected by their grafting onto resistant rootstocks, including $\mathrm{NAZ}_{4}$ (Vitis vinifera cv. 'Jighjigha' $\times$ Riparia Gloire) and $\mathrm{NAZ}_{6}($ V. vinifera cv. 'Gharaozum' $\times$ Kober $5 \mathrm{BB})$, or on self-rooted cultivars when the inoculated vines were monitored over a three-month period in a greenhouse. The weights of the galls induced on non-grafted vines by two of six strains of Agrobacterium vitis and Agrobacterium tumefacience biovar 1 were significantly different. $A$. vitis strain AG57 and Agrobacterium tumefacience biovar 1 strain 16/6 induced significantly larger galls (8.9 and $5.4 \mathrm{~mm}$ respectively) on 'Thompson seedless' and 'Red Sahebi' when these were growing as self-rooted plants than when grafted on $\mathrm{NAZ}_{4}$ and $\mathrm{NAZ}_{6}$. Observations over a four-year period in the field showed that there was no difference in crown gall incidence until the second year. Scions grafted onto rootstocks of $\mathrm{NAZ}_{4}$ and $\mathrm{NAZ}_{6}$ had a $21.5 \%$ and $6.8 \%$ incidence, compared to $55 \%$ for self-rooted vines. In another field experiment with naturally infected scions of $\boldsymbol{V}$. vinifera $\mathbf{c v}$. 'Asgari' (a very susceptible cultivar), crown gall was apparent on vines grafted onto all rootstocks after six years. The incidence of crown gall was $18 \%$ on $\mathrm{NAZ}_{6}$ compared to $68 \%$ on $\mathrm{NAZ}_{1}$. During a five-year period, many self-rooted vines died, compared to only a few scions grafted onto $\mathrm{NAZ}_{4}$ and $\mathrm{NAZ}_{6}$ rootstocks that died. At the end of the study, many pathogenic strains of Agrobacterium spp. were isolated from the roots of 'Thompson seedless' and 'Red Sahebi' vines, but not from roots or vines when $\mathrm{NAZ}_{4}$ and $\mathrm{NAZ}_{6}$ rootstocks were used.
\end{abstract}

Crown gall of grapevine, caused by Agrobacterium vitis, is a serious disease in many regions of the world. A. vitis, the predominant bacteria, can exist systemically in grapevines and can be disseminated in propagation material and infected vineyard soils (Burr \& Katz, 1983; Burr et al., 1987; Bishop et al., 1989). Cultivars of Vitis vinifera are responsible for more than $90 \%$ of grape production worldwide, but more than $95 \%$ of them are very susceptible to crown gall (Bishop et al., 1989; Ophel \& Kerr, 1990). Galls usually occur on the trunk just above the ground line, although aerial galls up to $1 \mathrm{~m}$ above the soil have been observed (Mahmoodzadeh, 2002). Also, A. vitis has been found in vineyards but not in nonvineyard soils (Burr \& Katz, 1984; Ferreira \& Van Zyl, 1986). When field soils are assayed for the presence of Agrobacterium spp., non-tumorigenic strains are often predominant (Burr et al., 1987). Studies have shown that some phylloxera-resistant rootstocks are also resistant to crown gall, e.g. Riparia Gloire and interspecific hybrids 3309C, 101-14 Mgt, $\mathrm{NAZ}_{1}, \mathrm{NAZ}_{2}, \mathrm{NAZ}_{4}, \mathrm{NAZ}_{5}$ and $\mathrm{NAZ}_{6}$ (Goodman et al., 1993; Stover, 1993; Süle et al., 1994; Stover et al., 1997; Mahmoodzadeh et al., 2004). In this research, the effects of crown gall-resistant rootstocks on the susceptibility of scions or self-rooted vines of three grapevine cultivars were studied.

\section{MATERIALS AND METHODS}

\section{Greenhouse experiment}

Five interspecific hybrids were used as resistant rootstocks (Table 1) (Mahmoodzadeh et al., 2004). One-bud scions taken from susceptible vines without visible symptoms of crown gall (Table 1) were hand-whip grafted onto $30 \mathrm{~cm}$ long cuttings of dormant rootstocks. Rooted cuttings of the same vines were used as the control treatment. Cuttings and scions were taken from the Viticulture Research Section of Khalat-Poushan Station, University of Tabriz, Tabriz, Iran. For callus formation, the scions and the cuttings were maintained in a hot-room $\left(28^{\circ} \mathrm{C}\right)$ for four weeks. Grafts and cuttings were potted separately into polyethylene bags with a diameter of $15 \mathrm{~cm}$ containing a mixture of loam soil, perlite and compost (1:1:2 in volume) and transferred to a greenhouse (20 to $28^{\circ} \mathrm{C}$ ).

When the new shoots were 25 to $30 \mathrm{~cm}$ long (in June) and had developed a brown periderm at the lower portion, the vines were inoculated by making wounds $\left(2 \mathrm{~mm}^{3}\right)$ at the fourth to tenth internodes on each plant with a scalpel and depositing $10 \mu \mathrm{L}$ of bacterial suspension (containing about $10^{10} \mathrm{CFU} / \mathrm{mL}$ ) into each wound as described by Stover et al. (1997). The experiment was carried out as factorial based on a randomised complete block design (RCBD) with four replications. In aggregate, 288 vines were used as the plant material for the experiment. Pathogenic strains of $A$. vitis and $A$. tumefaciens biovar 1 were selected as described by Matsumoto et al. (1992) (Table 2). Bacteria were grown for $48 \mathrm{~h}$ at $28^{\circ} \mathrm{C}$ on salts of yeast extract-beef (YEB) medium $(1 \mathrm{~g}$ yeast extract, $5 \mathrm{~g}$ beef extract, $5 \mathrm{~g}$ peptone, $5 \mathrm{~g}$ sucrose, and $0.5 \mathrm{~g}$ $\mathrm{MgSO}_{4}$ per $1 \mathrm{~L}$ distilled water) (Szegedi et al., 1984; Süle et al.,

"Corresponding author: Mahmoudzadeh_h@yahoo.com [Tel: +98441 2262222-6, Fax: +98 4412262221$]$

Acknowledgements: The authors wish to thank Dr M.R. Roozban, Y. Gholipoure and M. Golmohammadi for their technical assistance. 
TABLE 1

List of the studied grapevine genotypes.

\begin{tabular}{|c|c|}
\hline Hybrids as rootstocks* & Scion or self-rooted cultivar \\
\hline $\mathrm{NAZ}_{1}:$ V. vinifera cv. 'Jighjigha' & \multirow{6}{*}{$\begin{array}{l}V . \text { vinifera } \mathrm{cv} \text {. 'Red Sahebi' } \\
V . \text { vinifera } \mathrm{cv} \text {. 'Thompson seedless' } \\
V . \text { vinifera } \mathrm{cv} \text {. 'Asgari' }\end{array}$} \\
\hline × V. rupestris cv. 'Du Lot' & \\
\hline $\begin{array}{l}\mathrm{NAZ}_{2}: \text { V. vinifera cv. 'Alibaba' } \\
\times \text { V. rupestris } \mathrm{cv} \text {.'Du Lot' }\end{array}$ & \\
\hline $\begin{array}{l}\mathrm{NAZ}_{4}: \text { V. vinifera cv. 'Jighjigha' } \\
\times \text { Riparia Gloire }\end{array}$ & \\
\hline $\begin{array}{l}\mathrm{NAZ}_{5}: \text { V. vinifera } \mathrm{cv} . \text { 'Alibaba' } \\
\times 110 \mathrm{R}\end{array}$ & \\
\hline $\begin{array}{l}\mathrm{NAZ}_{6}: \text { V. vinifera cv. 'Gharaozum' } \\
\times \text { Kober } 5 \mathrm{BB}\end{array}$ & \\
\hline
\end{tabular}

*Mahmoodzadeh et al. (2004)

1994) and on selective media of RS (Roy \& Sasser, 1983). Two days prior to inoculation, strains were streaked onto potato dextrose agar (PDA) (Difco, Germany) and grown at $28^{\circ} \mathrm{C}$. Bacterial growth from the PDA was suspended in sterilised deionised water (SDW) and adjusted to an optical density $(600 \mathrm{~nm})$ of 1 . After inoculation, the plants were kept at $18^{\circ} \mathrm{C}$ in a room for $48 \mathrm{~h}$ and then transferred to the greenhouse. Each vine-bacterium combination was repeated four times. After three months, tumours that had formed on the scions were excised and weighted.

\section{Field experiments}

In September, four months after inoculation, the plants from the greenhouse experiment were placed outdoors and then covered with plastic in December for protection $\left(0\right.$ to $\left.10^{\circ} \mathrm{C}\right)$. In May, all the canes were pruned to two buds. The thickest canes were selected and inoculated with a $10 \mu \mathrm{L}$ bacterial suspension containing about $10^{7}$ bacteria, based on the method used by Süle et al. (1994). The strains were the same as those used on the plants in the greenhouse. The inoculated plants were planted in the field in a $2 \times 4 \mathrm{~m}$ spacing (four replications, four plants per bacterium). In November of each year, observations were made for the appearance of galls and for vine growth vigour and viability.

In a second field experiment, the same five rootstocks were used as earlier in the greenhouse. Scions were cut from naturally infected vines having many galls on the trunks of $V$. vinifera $\mathrm{cv}$. 'Asgari' at the start of the dormant season (in December). The scions were soaked in $1 \% \mathrm{NaOCl}(20 \%$ bleach) for $15 \mathrm{~min}$, and rinsed in sterilised distilled water. Each cane was numbered and tissue was sampled for the presence of $A$. vitis. The remainder of the cuttings from the canes was stored at 4 to $10^{\circ} \mathrm{C}$ in wet sand in plastic bags for 75 days. The presence of tumorigenic $A$. vitis was determined by incubating the basal section of the canes in wet perlite for 45 days at $28^{\circ} \mathrm{C}$. Newly-formed callus and roots were excised, ground in sterile distilled water and plated on RS medium (Roy \& Sasser, 1983). After incubation at $28^{\circ} \mathrm{C}$ for seven to 14 days, presumptive $A$. vitis colonies were tested for pathogenicity on sunflower (Helianthus annuus var. Record) and carrot slices (Daucus carota). A heavy smear of cells from each test strain (5 $\times 10^{8} \mathrm{CFU} / \mathrm{mL}$ ) was spread with a sterile toothpick onto stems of two- to four-week-old seedlings of sunflower (Bishop et al., 1989; Mahmoodzadeh et al., 2004). Carrot slices were spread across
TABLE 2.

Bacterial strains used in the experiments.

\begin{tabular}{lll}
\hline Strain & Characteristic & Origin \\
\hline A. vitis & Vitopine Ti ${ }^{\dagger}$ & USA, T.J. Burr \\
CG230 & Octopine Ti, LHR & Crete, C. Panagopoulos \\
AG57 & Octopine Ti & Germany, E. Bien \\
NW180 & Octopine Ti & Australia, A. Kerr \\
K1059 & & \\
A. tumefaciens biovar 1 & Nopaline Ti plasmid & Bulgaria, I. Popova \\
$1 / 12$ & Nopaline Ti plasmid & Hungary, S. Süle \\
\hline
\end{tabular}

Ophel and Kerr (1990).

Limited host range; Panagopoulos and Psallidas (1973).

each disk. The petri dishes were kept in a growth chamber in the dark at $28^{\circ} \mathrm{C}$, and the filter paper was periodically remoistened every $12 \mathrm{~h}$. Plants were assessed for the presence of tumours after 1.5 months. Canes found to be infected with tumorigenic strains were used to make cuttings for grafting. Rootstock cuttings were collected from crown gall- free mother plants of hybrids, handwhip grafted and placed in a hot-room $\left(28^{\circ} \mathrm{C}\right)$ for four weeks (standard heat callusing), except that only 40 randomly selected cuttings from 200 of each hybrid were tested for the presence of pathogenic bacteria. The grown grafts and ungrafted cuttings were planted into the nursery for the first growing season. One-year-old bare rooted plants were planted $2 \times 4 \mathrm{~m}$ apart in four replications (10 vines per replication) in field plots. Standard pruning, training and other cultural practices were done each year based on methods described by Goodman et al. (1993). Observations were recorded on the appearance of galls and the vigour of growth and viability of the vine in October of each year. At the end of the experiment (end of fourth year), the vines were dug out and their roots were evaluated for the presence of pathogenic bacteria as described previously.

\section{Statistical analysis}

Analyses of variance were performed using SAS statistical software (SAS Institute Inc., 1992). Student's t least significant difference (LSD) values were calculated at the 5\% significance level to facilitate comparison between treatment means.

\section{RESULTS AND DISCUSSION}

\section{Greenhouse experiment}

Visible galls developed on the inoculated shoots of two sensitive cultivars, 'Thompson seedless' and 'Red Sahebi' within six to eight weeks. Four of six bacterial strains (CG230, AG57, NW180, $\mathrm{K} 1059$ ) induced large tumours on very sensitive $V$. vinifera cultivars. The means of the size and weight of galls induced by different strains were not statistically different $(\mathrm{P}<0.05)$ for all hybrids, except for strains 16/6 and AG57, in which the galls on scions grafted onto $\mathrm{NAZ}_{4}$ and $\mathrm{NAZ}_{6}$ were significantly smaller (average size for 16/6 was $0.69 \mathrm{~mm}$ and for AG57 $1.42 \mathrm{~mm}$ ) than those on self-rooted vines $(5.53 \mathrm{~mm})$. Both $A$. vitis and $A$. tumefaciens biovar 1 strains were not equally tumorigenic in all treatments (Table 3). Strain AG57 (A. vitis) and 16/6 (A tumefaciens biovar 1$)$ induced bigger $(2.86 \mathrm{~mm})$ and more $(38.2 \%)$ galls than 


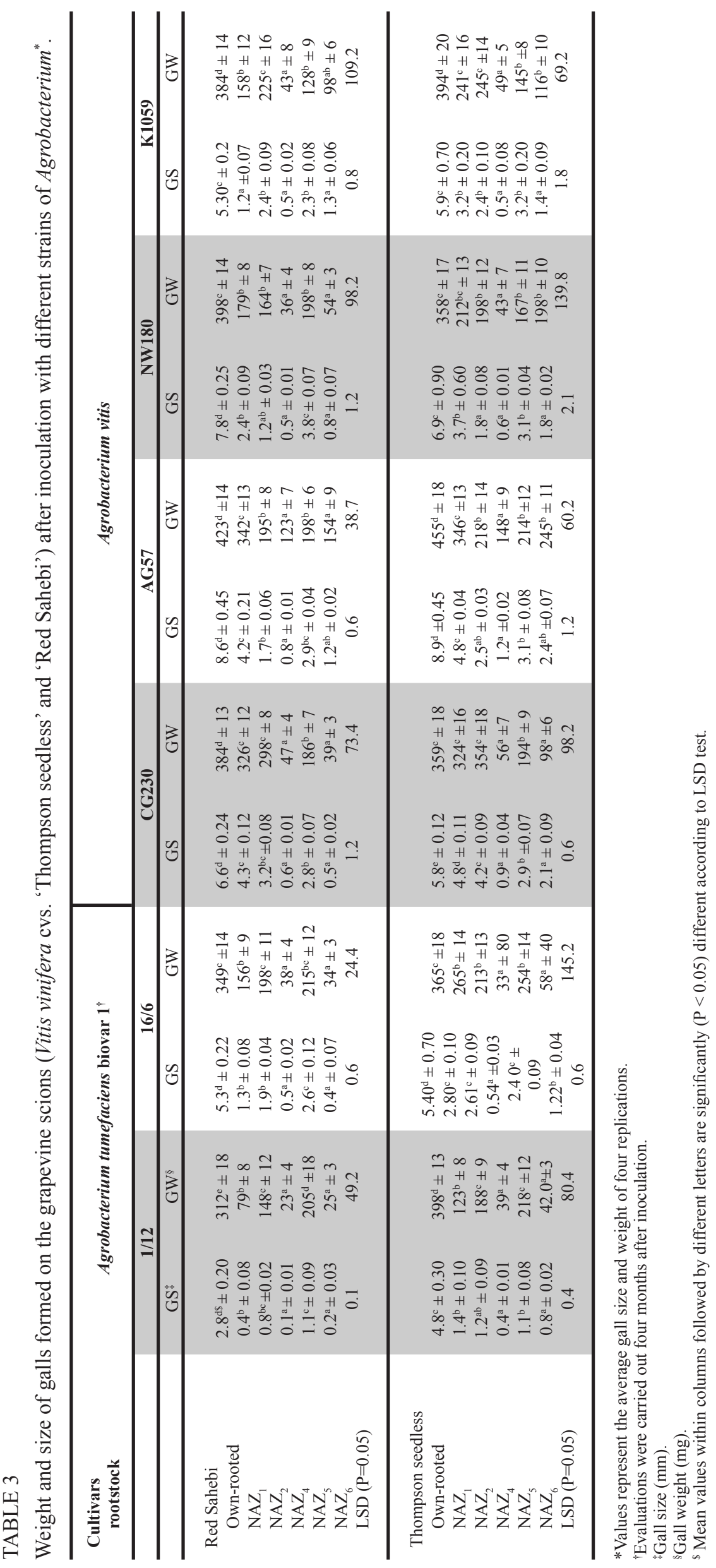

the other strains. Analysis of variance showed differences between genotypes of grapevine and strains of Agrobacterium spp. and interaction between grape genotypes $\times$ strains (Table 4 ).

\section{Field experiments}

All the plants used in the greenhouse experiment were re-inoculated and transported to the field for further observations in the following four years. Observations showed that all of the bacterial strains induced galls on the scions, but not an equal number, size or weight (Table 3). Rootstocks impacted the incidence of root galls. All cuttings of $\mathrm{NAZ}_{4}$ and $\mathrm{NAZ}_{6}$ remained free from galls, but other hybrids $\left(\mathrm{NAZ}_{1}, \mathrm{NAZ}_{2}\right.$ and $\mathrm{NAZ}_{5}$ ) showed small or a few galls typical of Agrobacterium infections on their trunks.

In the first year, no significant differences were observed between treatments, i.e. galls appeared in nearly equal numbers in all seven treatments. In the second and third years, more self-rooted plants became galled than scions on rootstocks (Fig. 1) and 19.2\% of self-rooted plants died by the end of the second year (Fig. 2 ). In the fourth year, the number of galled plants was higher for self-rooted plants and those on $\mathrm{NAZ}_{1}, \mathrm{NAZ}_{2}$ and $\mathrm{NAZ}_{5}$ compared to $\mathrm{NAZ}_{4}$ and $\mathrm{NAZ}_{6}$. The survival of scions on $\mathrm{NAZ}_{4}$ and $\mathrm{NAZ}_{6}$ rootstocks was $78.5 \%$ and $93.2 \%$, respectively, in contrast to $68.2 \%\left(\mathrm{NAZ}_{1}\right), 62.5 \%\left(\mathrm{NAZ}_{2}\right), 58.6 \%$ $\left(\mathrm{NAZ}_{5}\right.$ ) and $45 \%$ (self-rooted) (Fig. 2). Pieces of rootstocks and scions were indexed for the presence of pathogenic Agrobacterium spp prior to grafting. About $60 \%$ of the tested 'Thompson seedless' and 'Red Sahebi' led to canes that formed pathogenic colonies and only these were used to make cuttings for grafting, based on methods developed by Bazzi, Piazza and Burr (1987). The grafting success rate assessed prior to planting (200 cuttings grafted; two cultivars as scion) was $78 \%, 85 \%, 86 \%, 79 \%$ and $68 \%$ for the five hybrids used as rootstocks $\left(\mathrm{NAZ}_{1}\right.$, $\mathrm{NAZ}_{2}, \mathrm{NAZ}_{4}, \mathrm{NAZ}_{5}, \mathrm{NAZ}_{6}$ ) respectively. By the end of the first year in the nursery 142, 168, 161, 139 and 153 grafts remained in the nursery for transplanting. In the first year, no tumours were observed on any part of the grafts on $\mathrm{NAZ}_{4}$ and $\mathrm{NAZ}_{6}$. In the second year, galls were observed on many of the rootstocks (Fig. 1). In the third and fourth years, many plants developed galls, with $35 \%$ of the vines grafted on $\mathrm{NAZ}_{1} 28 \%$ on $\mathrm{NAZ}_{2}$, $4 \%$ on $\mathrm{NAZ}_{4}, 22 \%$ on $\mathrm{NAZ}_{5}$ and $6 \%$ on $\mathrm{NAZ}_{6}$ showing typical natural symptoms of crown gall disease. Over the five-year duration of the study, many galled plants died (Fig. 2).

Pathogenic isolates of $A$. vitis were recovered from the roots of $\mathrm{NAZ}_{1}, \mathrm{NAZ}_{2}, \mathrm{NAZ}_{5}$ and sensitive cultivars, but not from the roots of $\mathrm{NAZ}_{4}$ and $\mathrm{NAZ}_{6}$. Hybrids as rootstock and scion pieces 


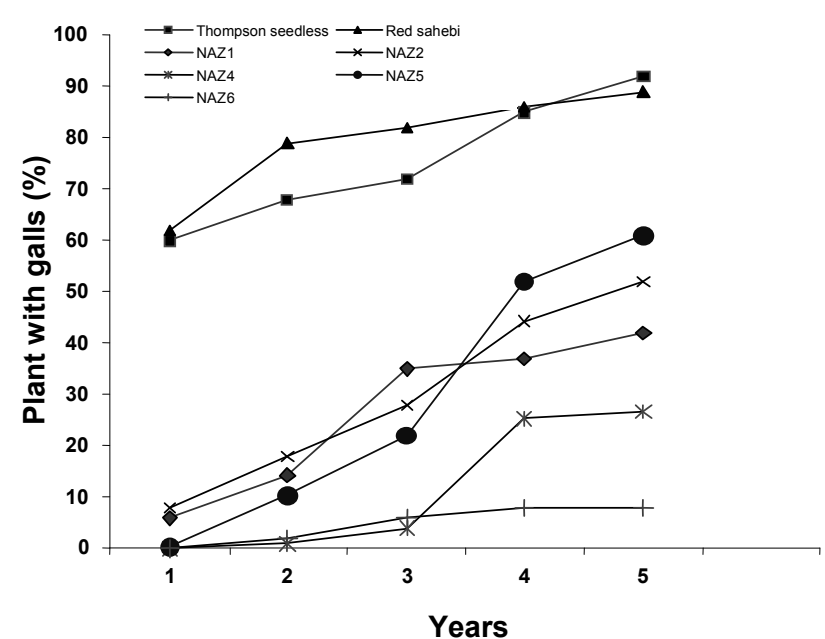

FIGURE 1

Effects of rootstocks on the appearance of gall on the scions after grafting naturally-infected scions onto healthy rootstocks.

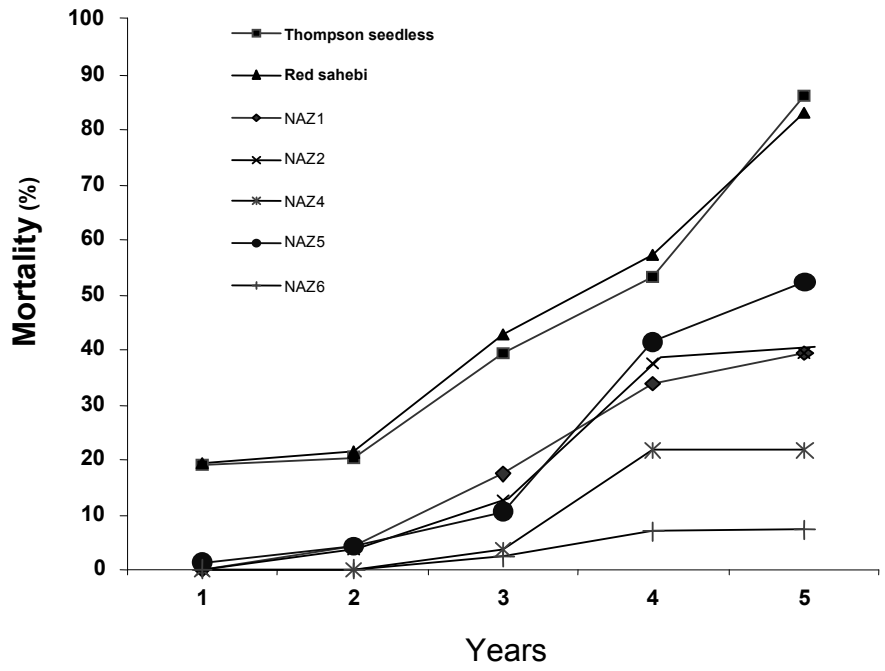

FIGURE 2

Effects of rootstocks on survival of scions after grafting naturally-infected scions onto healthy rootstocks.

TABLE 4

Analysis of variance for gall weight, size and dead plants after inoculation with different strains of Agrobacterium spp.

\begin{tabular}{|c|c|c|c|c|c|}
\hline \multirow{2}{*}{ Source of variation } & \multirow{2}{*}{ Degree of freedom } & \multicolumn{4}{|c|}{ Mean square } \\
\hline & & Gall size & Gall weight & Dead plants & Plants with galls \\
\hline Replication & 3 & $25.47 \dagger$ & $76.41 *$ & $4.138 \dagger$ & $18.287 \dagger$ \\
\hline Rootstocks (R) & 5 & $71.89 * *$ & $3149.876^{* *}$ & $284.625^{* *}$ & $4.286^{* *}$ \\
\hline V. vinifera cultivars $(\mathrm{V})$ & 1 & $14.12 \dagger$ & $83.26 \dagger$ & $18.985^{*}$ & $1.785 \dagger$ \\
\hline Agrobacterium strain (S) & 5 & $44.76 * *$ & $263.48 * *$ & $438.147 * *$ & $28.475^{* *}$ \\
\hline VS & 5 & $8.456 *$ & $123.71 \dagger$ & $21.497 \dagger$ & $17.487 \dagger$ \\
\hline RVS & 25 & $69.214^{*}$ & $846.211^{*}$ & $56.211 * *$ & $12.465 *$ \\
\hline Error & 213 & --------- & --------- & ---------- & --------- \\
\hline
\end{tabular}

$\dagger$ not significant, ${ }^{* * *}$ significant at $\mathrm{P}<0.05$ and $\mathrm{P}<0.01$ probability levels respectively.

were indexed prior to grafting for the presence of pathogenic Agrobacterium spp. None of the indexed rootstock cuttings (40 out 200) were infested with tumorigenic strains (Lehoczky, 1968). However, about $70 \%$ of the tested $V$. vinifera $\mathrm{cv}$. Asgari canes produced pathogenic (A. vitis) colonies (Fig. 3), and only these were used to make cuttings for grafting. Of all of the hybrids with 200 cuttings that were grafted, the grafting success rate assessed prior to planting was $56 \%, 36 \%, 74 \%, 81 \%$ and $79 \%$ for $\mathrm{NAZ}_{1}$, $\mathrm{NAZ}_{2}, \mathrm{NAZ}_{4}, \mathrm{NAZ}_{5}$ and $\mathrm{NAZ}_{6}$ respectively. At the end of the first year in the nursery, 41, 26, 38, 32 and 47 grafts on hybrids remained for transplanting respectively. After transplanting, the plants were observed for six years. In the first two years, no galls could be observed on any of the rootstocks, and only a few grafts became galled in the third year. By the sixth year nearly all of the previously infected vines on $\mathrm{NAZ}_{1} \mathrm{NAZ}_{2}$ and $\mathrm{NAZ}_{5}$ died. No more new galls could be observed on $\mathrm{NAZ}_{4}$ and $\mathrm{NAZ}_{6}$ (Fig. 3). As a result of this, and the fact that most vines grafted on $\mathrm{NAZ}_{4}$ and $\mathrm{NAZ}_{6}$ escaped the infection, $79 \%$ of the original vines remained alive and seemingly productive. Pathogenic isolates of $A$. vitis were recovered from the roots of $\mathrm{NAZ}_{1}, \mathrm{NAZ}_{2}$ and $\mathrm{NAZ}_{5}$, but no tumorigenic Agrobacterium were isolated from the roots of $\mathrm{NAZ}_{4}$ and $\mathrm{NAZ}_{6}$.

Although strain 16/6 of A. tumefaciens and strain AG57 of A. vitis induced galls on scions grafted on all rootstocks in this experiment, the gall weights and sizes were less (48\%) on the resistant rootstocks than on self-rooted $V$. vinifera vines. The other four bacterial strain vine combinations showed no significant differences. We found that a long time (more than two months) is needed for the expression of the rootstock effect on the scion. In the first year of the experiments there were no differences in gall formation among the rootstocks after inoculating with the bacteria. However, selfrooted vines were more galled at the end of the first year and the beginning of the second year. After three years, it became clear that vines grafted on $\mathrm{NAZ}_{4}$ and $\mathrm{NAZ}_{6}$ rootstocks were less susceptible to crown gall. Also, the results showed that, under field conditions using naturally-infected scions, the effect of resistant rootstocks on 


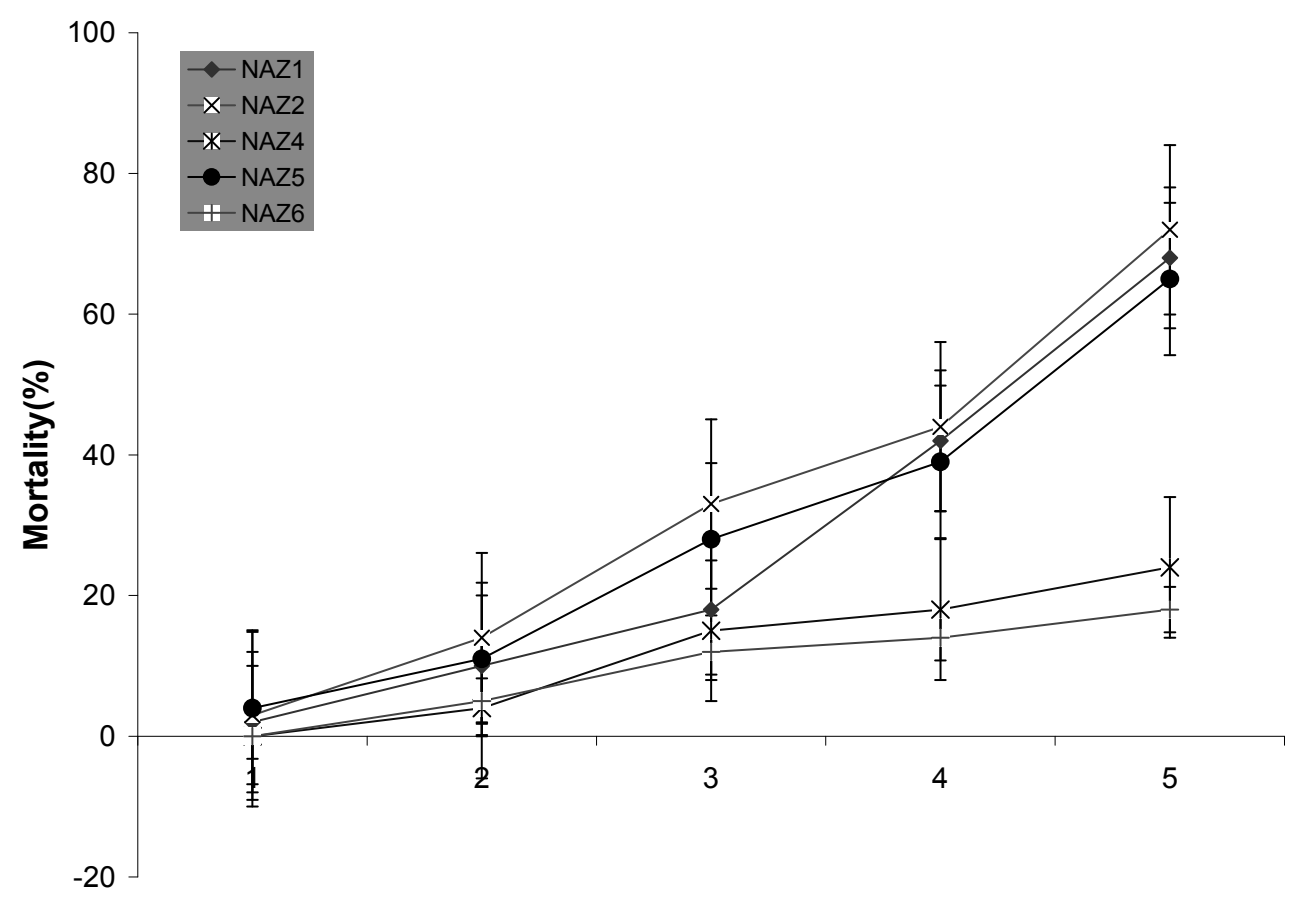

Years

\section{FIGURE 3}

Effects of rootstocks on the survival of scions (Vitis vinifera cv. Asgari) after grafting Naturally-infected scions onto healthy rootstocks. Each time point represents the mean of four replicates and indicates the calculated standard deviations.

crown gall infections became highly pronounced. The incidence of gall formation and the death of vines increased in the following years (after the fourth year). It can be hypothesised that either the bacterial number in the vascular tissues was not high enough in the first three years to induce galling (Burr \& Katz, 1984), or that the young vines were more resistant than the old ones (Burr et al., 1987). Riparia Gloire and some interspecific hybrids, such as Teleki 5C (Süle \& Burr, 1998), 3309C (Riparia tomentosa $\times$ Rupestris martin), 101-14 Mgt, $\mathrm{NAZ}_{4}$ and $\mathrm{NAZ}_{6}$ are resistant to the crown gall pathogen (Stover et al., 1997; Mahmoodzadeh et al., 2004), and are generally resistant to cold climates and have more winter hardiness. Therefore, they can be used as grape rootstocks in cold climates as well. In most cases, the infected trunk died and the new trunk emerging from below the earlier galls remained alive without any galling. The physiological basis for this is not clear. At present, one possible explanation is that compounds produced by the rootstock are translocated to the scion and may induce a loss of pathogenicity in populations of $A$. vitis (Mahmoodzadeh et al., 2004) or inhibit the extent of stable T-DNA integration (Stover, 1993). Therefore, when $A$. vitis bacteria in the vascular system migrate from scion to rootstock, the rootstock may have a mechanism that reduces bacterial survival. The decline in population may not be significant in the early years after grafting, but becomes more important as the vines age. In the light of this investigation, it is clear that rootstocks can greatly affect the severity of crown gall infection of grapevine.

Further long-term experiments are required to determine if similar effects exist with other rootstocks. The available rootstocks did not prevent the disease, but significantly reduced its severity. In Iran, $100 \%$ of vineyards have been established using sensitive cultivars of $V$. vinifera as self-rooted plants, which are highly susceptible to crown gall (Mahmoodzadeh, 2001; Mahmoodzadeh et al., 2003). In conclusion, we recommend that nurserymen should graft their scions onto resistant rootstocks to reduce the risk of crown gall.

\section{LITERATURE CITED}

Bazzi, C., Piazza, C. \& Burr, T.J., 1987. Detection of Agrobacterium tumefaciens in grapevine cuttings. EPPO Bulletin 17, 105-112.

Bishop, A.L., Burr, T.J., Mittak, V.L. \& Katz, B.H., 1989. A monoclonal antibody specific to Agrobacterium tumefaciens biovar 3 and its utilization for indexing grapevine propagation material. Phytopathol. 79, 995-998.

Burr, T.J. \& Katz, B.H., 1983. Isolation of Agrobacterium tumefaciens biovar 3 from grapevine galls and sap and vineyard soil. Phytopathol. 73, 163-165.

Burr, T.J. \& Katz, B.H., 1984. Grapevine cuttings as a potential site of survival and means of dissemination of Agrobacterium tamefaciens. Plant Disease 68, 976978 .

Burr, T.J., Katz, B.H. \& Bishop, A.L., 1987. Populations of Agrobacterium in vineyard and non-vineyard soils and grape roots in vineyards and nurseries. Plant Disease 71, 617-620.

Ferreira, J.H.S. \& Van Zyl, F.G.H., 1986. Susceptibility of grape-vine rootstock to strains of Agrobacterium tumefaciens biovar 3. S. Afr. J. Enol. Vitic. 7, 101-104.

Goodman, R.N., Grimm, R. \& Frank, M., 1993. The influence of grape rootstocks on the crown gall infection process and tumor development. Am. J. Enol. Vitic. 44, 22-26.

Lehoczky, J., 1968. Spread of Agrobacterium tumefaciens in the vessels of grapevine after natural infection. Phytopathol. Z. 63, 239-246. 
Mahmoodzadeh, H., 2001. A review on crown gall in Iranian vineyards. Ph.D. dissertation, Sciences and Research Unit of Islamic Azad University, Tehran, Iran (in Persian).

Mahmoodzadeh, H., 2002. Isolation of Agrobacterium vitis from grapevine roots, shoots, galls and from vineyards soil. Proc. $3^{\text {rd }}$ Intern. Iran and Russia Conf. "Agriculture and Natural Resources", 2002, Moscow, Russia. p. 21.

Mahmoodzadeh, H., Nazimeh, A., Majidi, I., Paygami, I. \& Khalighi, A., 2003. Effects of thermotherapy treatments on systemic Agrobacterium vitis in dormant grape cutting. J. Phytopathol. 151, 481-484.

Mahmoodzadeh, H., Nazimeh, A., Majidi, I., Paygami, I. \& Khalighi, A., 2004. Evaluation of crown gall resistance in Vitis vinifera and hybrids of Vitis spp. Vitis $42,75-79$.

Matsumoto, S., Ohel, K., Skene, K. \& Scott, N.S., 1992. Partial characterization of Agrobacterium vitis strains. Vitis 31, 195-203.

Ophel, K. \& Kerr, A., 1990. Agrobacterium vitis - new species for strains of Agrobacterium biovar 3 from grapevine. Int. J. Syst. Bacteriol. 40, 236-241.

Panagopoulos, C.G. \& Psallidas, P.G., 1973. Characteristics of Greek isolates of Agrobacterium tumefaciens (E.F. Smith \& Townsend). Conn. J. Appl. Bacteriol. $36,233-240$
Roy, M.A. \& Sasser, M., 1983. A medium selective for Agrobacterium tumefaciens biotype 3. Phytopathol. 73, 810. [Abstr.]

SAS Institute Inc., 1992. SAS/STAT guide for personal computers. 6th ed. SAS Institute Inc., Cary, NC, USA.

Stover, E.W., 1993. Resistance to crown gall in Vitis: studies directed toward the identification of crown gall resistant rootstocks. $\mathrm{PhD}$ dissertation, University of Maryland, USA.

Stover, E.W., Swart, H.J. \& Burr, T.J., 1997. Crown gall formation in a diverse collection of Vitis genotypes inoculated with Agrobacterium vitis. Am. J. Enol. Vitic. 48, 26-32.

Süle, S. \& Burr, T.J., 1998. The effect of resistance of rootstocks to crown gall (Agrobacterium spp.) on the susceptibility of scions in grapevine cultivars. Plant Pathol. 47, 84-88.

Süle, S., Mozsar, J. \& Burr, T.J., 1994. Crown gall resistance of Vitis spp. and grapevine rootstocks. Phytopathol. 84, 607-611.

Szegedi, E., Korbuly, J. \& Koleda, I., 1984. Crown gall resistance in East-Asian Vitis species and their $V$. vinifera hybrids. Vitis 23, 21-26. 